\title{
KAIP GREITUMO LAVINIMAS PALENGVINTO BE்GIMO PRATYBOMIS VEIKIA RAUMENŲ SUSITRAUKIMO JËGĄ IR GREITĮ?
}

\author{
Juozas Baltušnikas, Evaldas Dinevičius, Tomas Venckūnas \\ Lietuvos kūno kultūros akademija, Kaunas, Lietuva
}

\begin{abstract}
Juozas Baltušnikas. Sporto fiziologijos magistras. Lietuvos kūno kultūros akademijos doktorantas. Mokslinių tyrimų kryptis — judamuju
\end{abstract} gebėjimų vystymosi fiziologiniai ypatumai.

\begin{abstract}
SANTRAUKA
Mūsu nuomone, greitumas — vienas svarbiausiu judamuju gebejjimu. Jis, kultivuojant ¿vairias sporto šakas, pasireiškia skirtingomis formomis. Greitumo lavinimo pratybos skirtos sportininku raumenu susitraukimo ir atsipalaidavimo greičiui didinti. Vis tik sportinejje veikloje nepakanka gerai išugdyti susitraukinèjančius ir atsipalaiduojančius raumenis. Greta specialiuju gebejjimu svarbios ir kitos fizinès ypatybès. Pavyzdžiui, bègant trumpuosius nuotolius (sprinta) labai svarbu, kad raumenys atsispyrimo metu susitrauktu ne tik greitai, bet ir stipriai, t. y. išugdytu kuo didesni galingumq. Tai svarbu ir kitu šaku sportininkams. Visgi dèl jègos lavinimo dažnai nukenčia greitumas. Todèl, manytume, ypač svarbi ir bene sunkiausia sporto mokslo praktinè užduotis — surasti metodus, kaip didinant jèga nesumažinti raumenu gebèjimo greitai susitraukti ir atsipalaiduoti.
\end{abstract}

Tyrimo tikslas — nustatyti bègimo ìsigreitèjus palengvintomis salygomis pratybu ciklo lavinamaji poveiki didesnès jègos reikalaujantiems judamiesiems gebéjimams.

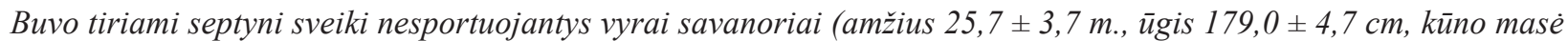
77,6 $\pm 8,4 \mathrm{~kg}$ ). Visq tyrima sudaré 3 etapai. Pirmuoju etapu laboratorijoje testavome vertikalaus šuolio iš vietos aukšti ir dešinès kojos izokinetinio lenkimo ir tiesimo per keli skirtingu kampiniu greičiu $\left(30-210^{\circ} / \mathrm{s}\right)$ didžiausia išugdomos jègos momentq o po 2-3 dienu tiriamieji didžiausiomis pastangomis atliko šiuos bègimo testus: $20 \mathrm{~m}$ iš aukšto starto tempiant 10\% kūno masès svori, $20 \mathrm{~m}$ iš aukšto starto, $20 \mathrm{~m}$ issigreitèjus, $20 \mathrm{~m}$ issigreitèjus tempiant guma (t. y. palengvintomis salygomis). Praejus 5-7 dienoms po šiu sprinto bégimo testu seke antras tyrimo etapas — dešimties pratybu ciklas, kurio metu buvo atliekami greitejimai palengvintomis salygomis (tempiant guma). Taip buvo siekiama padidinti greituma. Praèjus penkioms dienoms po šiu pratybu ciklo vèl tiriamieji buvo testuojami laboratorijoje (matuojamas šuolio aukštis ir raumenu galingumas), atlikti kontroliniai sprinto bègimo skirtingomis salygomis testai. Visi testai ir pratybos atliekami didžiausiomis tiriamuju pastangomis.

Po greitumo lavinimo pratybu pagerejo $20 \mathrm{~m}$ bègimo isigreitèjus tempiant guma (palengvintomis sqlygomis) ir $20 \mathrm{~m}$ bégimo isigreitejus rezultatai $(p<0,01)$. Bègimo iš aukšto starto tempiant svorí, bégimo iš aukšto starto ir šuoliu $\dot{\jmath}$ aukštti iš vietos rezultatai nepakito. Greitumo lavinimo pratybu ciklas neigiamai paveike didesnés jègos reikalaujančiu pratimu (kojos tiesimo ir lenkimo $30^{\circ} /$ s greičiu) rezultatus, nors koja tiesiant ir lenkiant didesniu greičiu $\left(60-210^{\circ} / \mathrm{s}\right)$ maksimalioji raumenu galia nepakito.

Raktažodžiai: bėgimas palengvintomis salygomis, maksimalusis bėgimo greitis, sprinto bėgimo pratybos, adaptacija.

\section{IVADAS}

$\mathrm{G}$ reitumas laikomas žmogaus gebėjimu atlikti judesius ir veiksmus tam tikromis sąlygomis per kuo trumpesni laiką (Karoblis, 2003). Sporto srityje greitumas pasireiškia ivairiomis formomis: jègos greitumu, ištvermès greitumu, greitumo jèga ir pan. (Komi, 1992). Kultivuojant daugeli sporto šakų svarbiausia veikla atliekama bėgant. Didžiausią galimą išvugdyti bėgimo greitị lemia tiek žingsnių ilgis, tiek jų dažnis (Stanislovaitis ir kt., 2006), tad daugelis bègiku bando rasti sau optimalu žingsnių ilgio ir dažnio santyki (Donati, 1995). Sprinto bėgimo greitis labiau priklauso nuo žingsnių dažnio nei nuo jų ilgio (Озолин, 2002). Žingsnių dažnis tik šiek tiek tobulëja treniruojantis (Stanislovaitis ir kt., 2006). Be to, per daug išugdyta raumenu jèga ar ištver- 
mè sulètina maksimaluji raumenų susitraukimo ir atsipalaidavimo greiti, kartu ir žingsnių dažni (Widrick et al., 2002).

Geriausiujų šių dienų trumpujų nuotolių bėgikų maksimalusis bėgimo greitis viršija $12 \mathrm{~m} / \mathrm{s}$. Vaikinų, bėgančių $11 \mathrm{~m} / \mathrm{s}$ greičiu, atremties fazès trukmé siekia $90 \mathrm{~ms}$, lèkimo - $115 \mathrm{~ms}$ (Озолин, 2002). Per $90 \mathrm{~ms}$ atremties fazèje reikia išugdyti kuo didesnę kojos tiesimo jègą, reikalingą perkeliant kūną i priekị. Todèl, mūsų nuomone, viena aktualiausių trumpuju nuotolių bėgikų rengimo problemu — jègos didinimas nemažinant raumenų gebejjimo greitai susitraukti ir atsipalaiduoti. Tyrimo metu iškeliamas klausimas: ar taikant greitumo lavinimo pratybas imanoma padidinti jègą ir greitumą?

Šio tyrimo metu per greitumo lavinimo treniruotę bègimo pratimai buvo atliekami palengvintomis salygomis. Tokie pratimai lavina maksimaluji raumens susitraukimo ir atsipalaidavimo greiti žingsnių dažni (Stanislovaitis ir kt., 2006). Nors yra žinomos kelios bėgimo palengvintomis sąlygomis modifikacijos (bėgimas į nuokalnę, pavejui, tempiant guma ir kt.), tokie pratimai dar retai taikomi sporto trenerių; dažniausiai tai daroma rezultatu stabilizacijos laikotarpiu norint dar labiau pagerinti sprinto bėgimo rezultatus.

Kol kas nėra visiškai aišku, nuo ko priklauso ir kiek gali lavèti greitumas, koks būtų bėgimo isigreitejus tempiant guma (ar kitaip palengvinant sąlygas) treniravimo poveikis didesnès jègos reikalaujantiems judamiesiems gebejimams. Šis tyrimas aktualus tuo, kad juo netiesiogiai bandoma nustatyti, ar galima padidinti raumenu jèga nesuletinant maksimaliojo raumenų susitraukimo ir atsipalaidavimo greičio.
Tyrimo tikslas — nustatyti, kaip bėgimo ịsigreitejus palengvintomis sąlygomis pratybu ciklas, skirtas greitumui lavinti, veikia didesnès jègos reikalaujančius judamuosius gebẻjimus.

\section{TYRIMO METODIKA}

Tiriamieji. Buvo tiriami septyni sveiki nesportuojantys suaugę vyrai (amžius 25,7 $\pm 3,7 \mathrm{~m}$., ūgis $179,0 \pm 4,7 \mathrm{~cm}$, kūno masė prieš pratybu ciklą $77,6 \pm 8,4 \mathrm{~kg}$ ).

Metodika. Tyrimas buvo atliekamas Lietuvos kūno kultūros akademijos laboratorijoje ir manieže. Viso tyrimo eiga (1 pav.) rodo, kad prieš ir po dešimties pratybų, kurių metu treniruojamasi bègant $20 \mathrm{~m}$ isigreitèjus tempiant guma (palengvintomis salygomis), buvo atlikti tokie patys testai:

1) šuoliu testai;

2) kojos lenkimo ir tiesimo per kelio sąnari dinamometrija;

3) sprinto bègimo testai.

Prieš $20 \mathrm{~m}$ bègimą i̊sigreitejus tempiant guma (palengvintomis sąlygomis) ir po jo testu tikslas - nustatyti ir įvertinti testuojamuju rodikliu pokyčius.

Pulso dažnio matavimas. Tiriamajam bėgant pramankštos metu stabtelejjus, bevardžiu pirštu ispaudžiama miego arterija. Per $10 \mathrm{~s}$ buvo suskaičiuojami širdies susitraukimų tvinksniai. Gautas skaičius dauginamas iš 6 .

$20 \mathrm{~m}$ bėgimo įsigreitėjus tempiant guma (palengvintomis sąlygomis) pratybos.

Pramankšta. Pramankštos esmè — parengti organizmą didžiausio greitumo pratyboms. Jų metu tiriamieji atlikdavo tokius pratimus:

1) bėgo 800-1200 m ristele (pulsas iki 130 tv. / min);

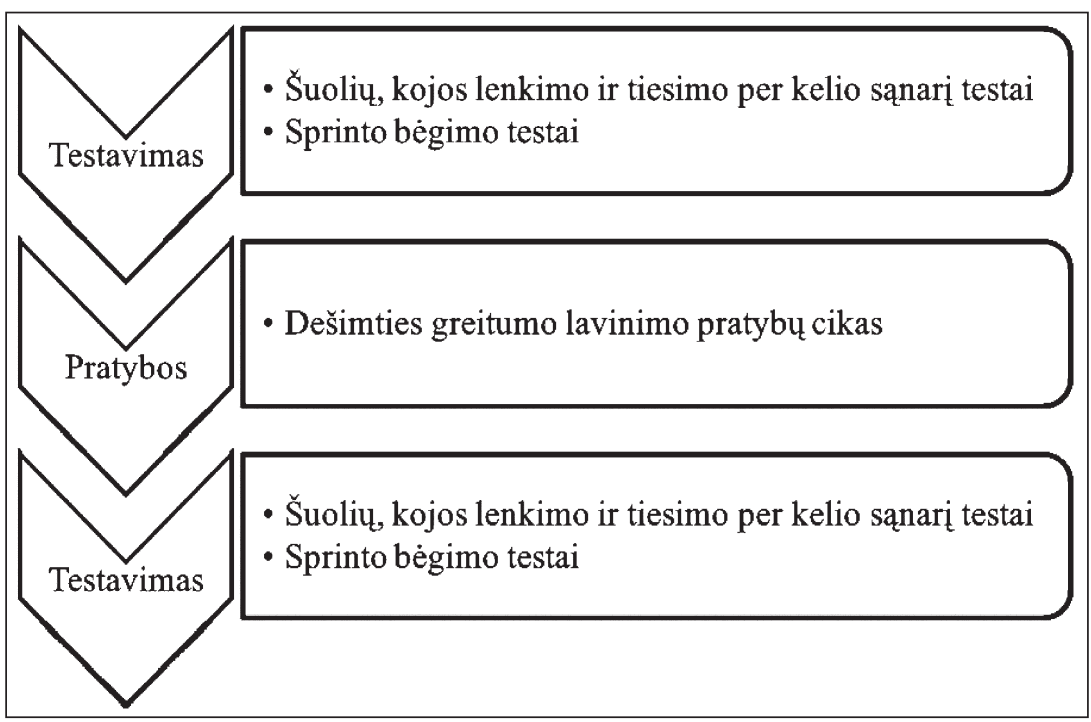

1 pav. Tyrimo eiga 
2) viso kūno raumenu tempimo pratimus, akcentuojant kojų raumenis (trukmè $15-20 \mathrm{~min}$ );

3) $30 \mathrm{~m}$ ilgio, $5-7$ ịvairius specialiuosius bègimo pratimus ( $40-60 \%$ didžiausiu pastangu);

4) tris 30 m nuotolio greitèjimus atitinkamai įdedant $60,70,80 \%$ didžiausių pastangų.

Pratybos. Po pramankštos tiriamieji dukart bėgdavo $20 \mathrm{~m}$ issigreitejus didžiausiomis pastangomis, buvo matuojamas laikas. Isigreitejjimo atstumas $20 \mathrm{~m}$. Isigreitejimo laikas nebuvo matuojamas. Šių bègimų tikslas — parengti organizmą didžiausio greitumo lavinimo krūviui. Tada bėgama $20 \mathrm{~m}$ tempiant guma isigreitejus, matuojamas laikas. $20 \mathrm{~m}$ nuotolis buvo suskirstytas i du ruožus po $10 \mathrm{~m}$, o elektroniniai laiko matavimo stoveliai pastatyti ties starto linija, 10 ir $20 \mathrm{~m}$ nuo jos. Isigreitejjimo atstumas $20 \mathrm{~m}$. Bègimu kartojimu skaičius priklausydavo nuo individualiu žmogaus ypatumų. Poilsis tarp pratimų 2-4 min. Tiriamieji pratybas baigdavo, kai rezultatas dèl nuovargio pablogedavo $60 \mathrm{~ms}$ arba daugiau, lyginant su tos dienos geriausiu rezultatu. Mažiausias bėgimų skaičius buvo trys kartai, didžiausias aštuoni. Tempimui buvo naudojama $15 \mathrm{~m}$ ilgio apvali sidabro spalvos guma „Thera-Band“ (Vokietija). Gumos itempimo stiprumas optimalus, t. y. reguliuojamas pagal individualius tiriamojo gebejjimus: tempti bègimo kryptimi reikèdavo taip, kad tiriamasis pasiektu geriausią bėgimo rezultata. Per stiprus tempimas neduoda puikiu rezultatu, nes tiriamasis negeba taip greitai atlikti judesių ir todèl pradeda stabdytis pablogindamas savo rezultatą. Per silpnas tempimas neleidžia pasiekti didelio bėgimo greičio, kadangi reikia idèti daugiau jègu atsispiriant. Didejant tiriamojo meistriškumui, optimalus gumos tempimas taip pat didèdavo.

Baigiamoji pratybu dalis. Po greitejjimu tiriamieji bègdavo $200-400 \mathrm{~m}$. Pulsas neturèdavo pakilti iki $120 \mathrm{tv}$. / min. Tada atlikdavo tempimo pratimus, kuriu trukme 5 min.

Pradinis pratybų išdèstymas per savaitę -2 kartai, tarp pratybu $2-3$ dienos poilsio. Atsigavimo laikas buvo reguliuojamas pagal superkompensacijos fenomena, stebint $20 \mathrm{~m}$ bègimo įsigreitëjus ir $20 \mathrm{~m}$ bėgimo issigreitèjus tempiant guma rezultatu pokyti. Laikas buvo lyginamas su praejjusiu pratybu laiku, t. y. tiriamasis turèdavo ilsètis tiek, kad kitose pratybose pagerintu savo bėgimo rezultata. Jeigu tiriamasis nepagerindavo rezultato, tai jo atsigavimo laikas būdavo pailginamas $1-5$ dienomis. Tiriamieji tyrimo laikotarpiu negalèdavo užsiimti kita fizine veikla, vartoti svaigiuju gèrimų, narkotinių medžiagų, miegoti mažiau nei 8 valandas per parą. Likus trim mènesiams iki tyrimo pradžios, tiriamieji negalejo sportuoti daugiau kaip kartą per savaitę.

Laikas buvo matuojamas naudojant elektrinius jutiklius VD-250N/VD-250P (Optex FA, Stokholmas, Švedija). Jutikliai buvo iškelti i $1,15 \mathrm{~m}$ aukšti naudojant „Hama Tripod Star 700 EF“ stovelius. Pagrindinis kompiuteris „SMB-1 H-T“ (Katra) sumuodavo ir pateikdavo rezultatus. Buvo sudèti 3 tokie stoveliai su jutikliais, kurie atskirai matuodavo kiekvieną dešimti metrų ir visą $20 \mathrm{~m}$ atstumą.

Prieš 2-3 dienas iki greitumo lavinimo ciklo ir praejus 5-7 dienoms po jo atliekami du testai:

1) šuoliu, kojos lenkimo ir tiesimo;

2) bègimo.

Šuolių, kojos lenkimo ir tiesimo per kelio sąnari dinamometrija. Prieš ši testavimą visi tiriamieji buvo pasveriami. Tada buvo daroma pramankšta, kurią sudarè: 8 minučiu veloergometrija (pulsą išlaikant ne didesni kaip 130 tv. / min) ir 5 minučių trukmès tempimo pratimai. Tiriamieji prieš tyrimą jau buvo supažindinti su šuolių ir koju dinamometrijos atlikimo technika. Po pramankštos jie didžiausiomis pastangomis atliko šuolio i aukšti iš vietos amortizuojamai pritupiant ir šuolio $\dot{i}$ aukšti iš padèties pusiau pritūpus (kampas per kelio sąnari - iki $90^{\circ}$ ) testus. Rankos šuolių metu buvo laikomos ant liemens. Kiekvieną šuolio i aukšti būdą tiriamieji pabandydavo atlikti 3 kartus. Poilsio tarpai — nuo 1 iki 2 minučių. Fiksuojami buvo tik geriausio bandymo duomenys. Šuolių rezultatams testuoti buvo naudojama jègos plokštè (Kistler, Vintertūras, Šveicarija). Pagal lèkimo ore laiką buvo skaičiuojamas šuolio aukštis $(\mathrm{cm})$ naudojantis formule:

$$
\mathrm{h}=\mathrm{t}_{\mathrm{p}}{ }^{2} \times 122,6 \quad\left(\mathrm{t}_{\mathrm{p}}-\text { lèkimo fazés trukmè }\right)
$$

Po šuolių testavimo išmatavome dešinès kojos šlaunies priekinių ir užpakalinių (kelio tiesiamuju ir lenkiamujų) raumenų didžiausią jègos momentą izokinetiniu režimu. Tuo tikslu buvo naudojamas izokinetinis dinamometras (Biodex Medical System 3, Niujorkas, JAV). Tiriamieji buvo sodinami i dinamometro kèdę, testuojama dešinè koja. Kelio anatominé sąnario ašis nustatoma ir sulyginama su dinamometro dinaminès apkrovos mazgo ašimi. Nustatoma visa kelio sąnario judesio amplitudẻ. Mažinant viso kūno svyravimus, tiriamieji buvo apjuosiami pečių, liemens ir šlaunies diržais. Blauzdos tiesimo ir lenkimo didžiausias jègos momentas buvo matuojamas judesius atliekant: 
1) $30^{\circ} / \mathrm{s}$ kampiniu greičiu (vienas po kito atliekami du bandymai);

2) $60^{\circ} / \mathrm{s}$ greičiu (trys bandymai);

3) $120^{\circ} / \mathrm{s}$ greičiu (trys bandymai);

4) $210^{\circ} / \mathrm{s}$ greičiu (keturi bandymai).

Buvo fiksuojami kiekvieno greičio geriausio bandymo duomenys. Tarp serijų tiriamieji ilsėdavosi 2 minutes.

Sprinto bėgimo testai. Antras testavimas vyko praejjus $2-3$ dienoms po pirmojo. Testavimo metu buvo atliekama tokia pati pramankšta kaip prieš greitumo pratybas. Po pramankštos tiriamieji dukart bėgdavo po $20 \mathrm{~m}$ :

1) iš aukšto starto tempiant svori (10\% tiriamojo kūno masès) ${ }^{*}$;

2) iš aukšto starto;

3) isigreitejus;

4) i̇sigreitejjus tempiant guma.

Buvo fiksuojamas geriausias kiekvieno nuotolio ruožo i̇veikimo laikas skirtingomis sąlygomis. Poilsis tarp pratimu $30-180 \mathrm{~s}$.

Matematinès statistikos analizè buvo atlikta kompiuterine programa Microsoft Office Excel 2007. Buvo skaičiuojama ir rezultatų skyriuje pateikiama: aritmetinis vidurkis, vidutinis standartinis nuokrypis, skirtumo tarp vidurkiu statistinis patikimumas (p). Aritmetinių vidurkių skirtumo patikimumas nustatytas naudojant Stjudento $t$ kriteriju priklausomoms imtims. Skirtumo patikimumas laikytas reikšmingu, kai $\mathrm{p}<0,05$.

\footnotetext{
* Tempiamas svoris buvo tvirtinamas prie virvès ir gulèdavo ant maniežo guminès dangos, kitas virvès galas buvo pritvirtintas prie diržo, juosiančio tiriamojo juosmenị. Pasipriešinimą sukeldavo svorio trintis su gumine maniežo danga. Svarmenys buvo sudedami ir pritvirtinami ant specialios metalinès plokštės „slidès“, kurios dugnas, tempimo metu besiliečiantis su maniežo danga, lygus. „Slidès“ svoris priskaičiuojamas prie viso tempiamo svorio.
}

\section{REZULTATAI}

Po greitumo lavinimo pratybu ciklo tiriamieji pagerino $20 \mathrm{~m}$ bègimo isigreitejus tempiant guma $(\mathrm{p} \leq 0,01)$ ir $20 \mathrm{~m}$ bėgimo issigreitejus rezultatus $(\mathrm{p} \leq 0,01)$ (2 pav.). Vyrauja tendencija, kad $20 \mathrm{~m}$ bėgimo îsigreitejus tempiant guma rezultatu prieaugiai yra didesni nei $20 \mathrm{~m}$ bėgimo isigreitèjus. $20 \mathrm{~m}$ bėgimo iš aukšto starto tempiant svori ir $20 \mathrm{~m}$ bėgimo iš aukšto starto rezultatai nepakito ( $\mathrm{p}>0,05)(2$ pav.).

Po greitumo lavinimo pratybų tiriamujų šuolio i aukšti iš vietos su itūpstu ir šuolio i aukštį iš vietos be itūpsto rezultatai nepasikeite (3 pav.).

Po didžiausio greitumo lavinimo pratybų tiriamieji pablogino kojos tiesimo rezultatus esant $30^{\circ} / \mathrm{s}$ greičiui $(\mathrm{p} \leq 0,01)(4 \mathrm{pav}$.). Esant kitiems greičiams $\left(60-210^{\circ} / \mathrm{s}\right)$ vyrauja prastejanti jègos rezultatų tendencija, kai kojos tiesimo greitis didejja ( $p>0,05)$ (4 pav.).

Po didžiausio greitumo lavinimo pratybų tiriamieji pablogino kojos lenkimo rezultatus esant $30^{\circ} / \mathrm{s}$ greičiui $(\mathrm{p} \leq 0,01)(5 \mathrm{pav}$.). Esant kitiems greičiams $\left(60,120,210^{\circ} / \mathrm{s}\right)$ vyrauja prastejanti jègos rezultatų tendencija, kai kojos tiesimo greitis didèja $(\mathrm{p}>0,05)(5$ pav.).

\section{REZULTATŲ APTARIMAS}

Jau 10 metų vaikų kojų judesių didžiausias dažnumas yra toks pat kaip ir suaugusiujų — apie 250 žingsnių per minutę, o didelio meistriškumo sprinteriai per minutę atlieka tik keliolika žingsnių daugiau už vaikus (Harre, 1994). Bègimo greitis daugiausia priklauso nuo žingsnių dažnumo, o ne nuo žingsnio ilgio (Озолин, 2002). Vadinasi, svar-

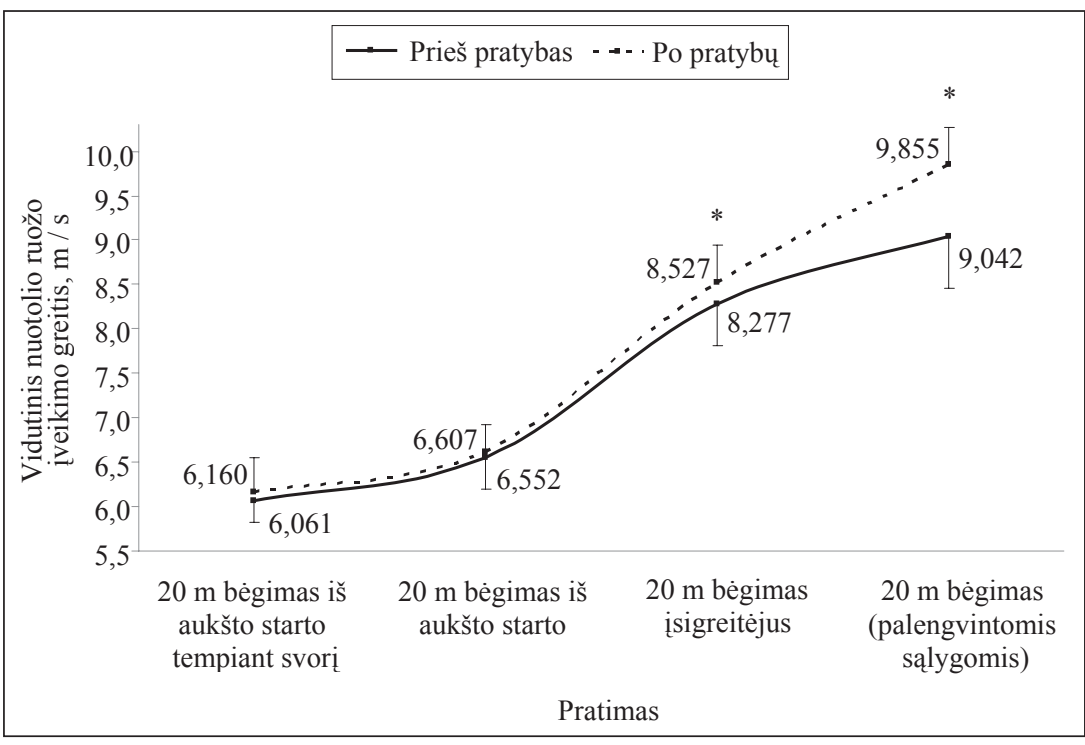

2 pav. Jègos ir greičio kreivès prieš greitumo lavinimo pratybų ciklą ir po jo
Pastaba. * — reikšmingas rezultatų skirtumas prieš greitumo lavinimo pratybų ciklą ir po jo $(\mathrm{p} \leq 0,01)$. 
3 pav. Vertikalių šuolių rezultatai prieš greitumo lavinimo pratybų ciklą ir po jo $(\mathbf{p}>0,05)$
4 pav. Kojos tiesimo jègos ir greičio kreivès prieš greitumo lavinimo pratybų ciklą ir po jo
Pastaba. * — reikšmingas rezultatu skirtumas prieš greitumo lavinimo pratybų ciklą ir po jo $(\mathrm{p} \leq 0,01)$

5 pav. Kojos lenkimo jègos ir greičio kreivès prieš greitumo lavinimo pratybų ciklą ir po jo
Pastaba. * — reikšmingas rezultatų skirtumas prieš greitumo lavinimo pratybų ciklą ir po jo $(\mathrm{p} \leq 0,01)$.
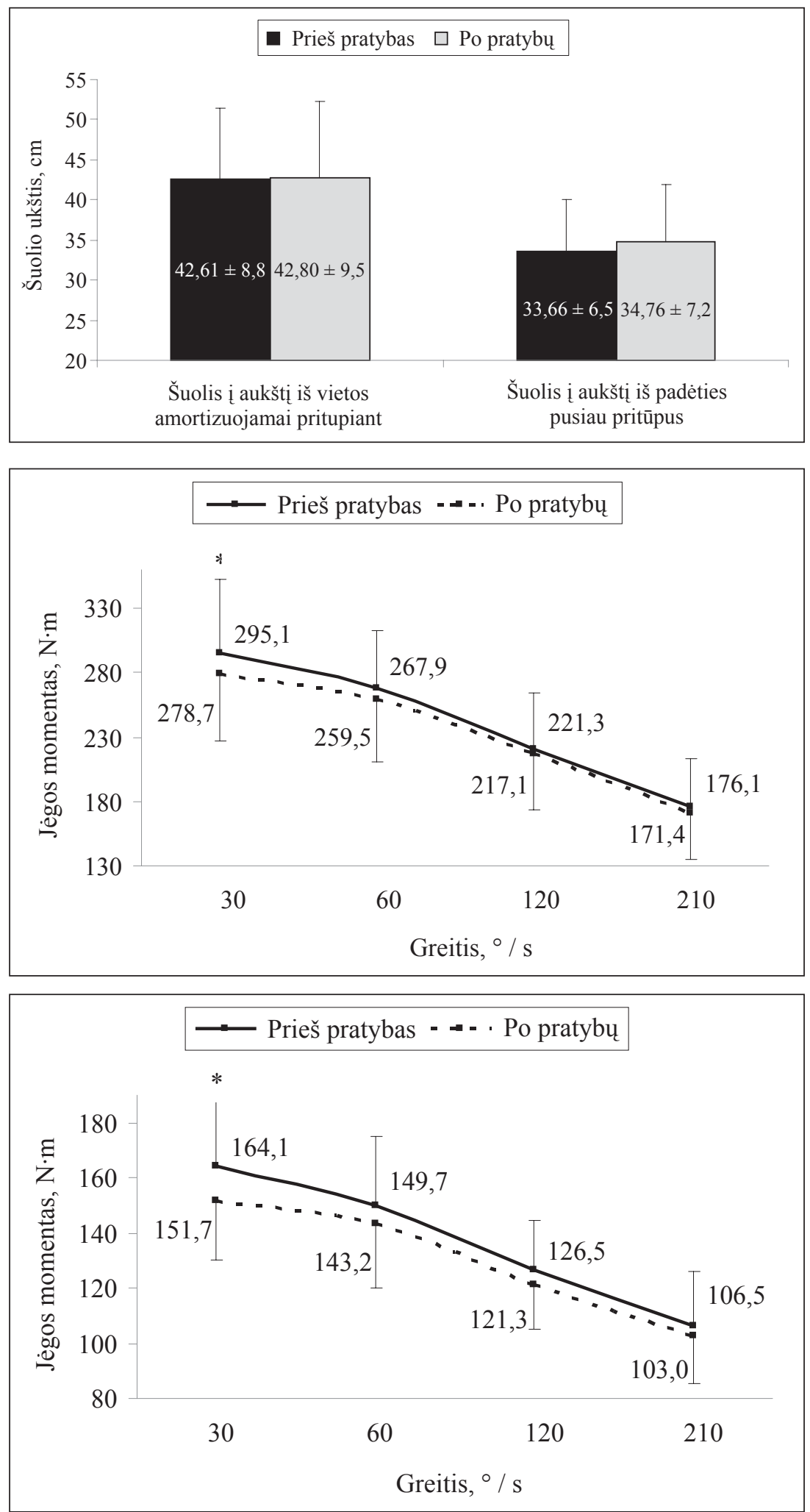

biausias greito bėgimo komponentas — žingsnio dažnis — tik šiek tiek tobulèja treniruojantis (Stanislovaitis ir kt., 2006). Mūsų tyrimo pagrindinè paskirtis buvo pagerinti $20 \mathrm{~m}$ bėgimo issigreitejus tempiant guma (palengvintomis sąlygomis) ir $20 \mathrm{~m}$ bėgimo isigreitejus greiti bei nustatyti bégimo tempiant guma (palengvintomis salygomis) lavinamaji poveiki didesnès jëgos reikalaujantiems judamiesiems gebejjimams. Greitumo pratybomis pavyko padidinti $20 \mathrm{~m}$ bėgimo isigreitejus tempiant guma ir $20 \mathrm{~m}$ bègimo isigreitejus rezultatus. Mūsų pratybose buvo atliekami greitejjimai palengvintomis sąlygomis, vadinasi, žingsnio dažnis (daug greitumo ir mažai jègos reikalaujantis kom- 
ponentas) buvo treniruojamas kur kas labiau negu žingsnio ilgis (daug jègos reikalaujantis bėgimo komponentas). Todèl mūsų didžiausio greitumo prieaugiai iš dalies prieštarauja $\mathrm{A}$. Stanislovaičio ir kt. (2006) teiginiui, kad žingsniu dažnis tik šiek tiek tobulèja treniruojantis. Šuolių aukštis po greitumo pratybų nepakito. Idomu tai, kad šuolio i aukštị rezultatai nesuprastèjo, nes po mūsų pratybu kojos lenkimo ir tiesimo rezultatai esant $30^{\circ} / \mathrm{s}$ greičiui suprastejjo. Neaptikome greitumo didinimo ir jo poveikio didesnés jëgos reikalaujantiems pratimams tyrimu.

Nustebino kojos lenkimo ir tiesimo per kelio sąnarị mažu $\left(30^{\circ} / \mathrm{s}\right)$ greičiu rezultatu pablogèjimas. Šie rezultatai labai panašūs i jègos sumažejimą po raumens atrofijos nustojus sportuoti (Andersen et al., 2005) arba koją imobilizavus (Deschenes et al., 2008). Tokio tipo raumenu atrofija padidina greito tipo sunkiuju miozino grandžiu aktyvumą (Andersen et al., 2005). Raumens skaidulu kompozicijos pokyčius lemia i sarkoplazmą išmetami $\mathrm{Ca}^{2+}$ (Chin et al., 1998). Nustatyta, kad nuolatine $10 \mathrm{~Hz}$ stimuliacija skatina greitojo tipo raumeniniu skaidulu virsmą lètosiomis (Williams et al., 1986; Sreter et al., 1987). Panašus motoriniu vienetu nervinis aktyvumas vyrauja lavinant aerobinę ištvermę. Raumeniui dirbant tokiu režimu, skaidulose daugèja aktyvaus kalcineurino ir defosforilinto NFAT (Hoey et al., 1995). Raumenų skaidulų pokyčiai iš lètojo tipo i greitaji vyksta tada, kai į raumenu sarkoplazmą išmetama daug $\mathrm{Ca}^{2+}$ (Chin et al., 1998). Panašus motoneurono aktyvumas būna taikant mūsu pratybas, kai atliekamas intesyvus, bet trumpalaikis ilgo atsigavimo reikalaujantis fizinis krūvis. Tokiais atvejais kalcineurinas nesuaktyvinamas (Chin et al., 1998). Neaktyvus kalcineurinas negeba defosforilinti NFAT, dèl to i ši procesą itraukiamos greitosios raumeninès skaidulos (Chin et al., 1998). Seniai žinoma, kad kalcineurino signalinio kelio nuslopinimas skatina greitojo tipo raumeninių skaidulų raišką (Brooke, Kaiser, 1970). Mūsu tyrimo metu pastebètą jègos rodiklių sumažèjimą po didžiausio greitumo pratybu galima paaiškinti taip: kalcineurinas taip pat yra atsakingas ir už raumens hipertrofija. Buvo atliktas tyrimas, kurio rezultatai teigia, kad užslopinus kalcineurino aktyvumą ciklosporinu A buvo sustabdytas kalcineurino aktyvumas ir raumens hipertrofija (Dunn et al., 1999; Mitchell et al., 2002; Sakuma et al., 2008). Taip pat pastebèta, kad po kalcineurino nuslopinimo pradeda vystytis raumens atrofija (Oh et al., 2006). Yra ir tam prieštaraujančiu tyrimu — po kalcineurino nuslopinimo nebuvo sustabdyta raumens hipertrofija (Bodine et al., 2001). Patys naujausi tyrimai rodo, kad kalcineurinas reguliuoja tik I tipo raumeninių skaidulu hipertrofiją (Sakuma, Yamaguchi, 2010).

Labai įdomu sužinoti, ar tikrai mūsų greitumo lavinimo pratybos slopino kalcineurino aktyvumą ir kaip jos paveikè raumenų kompoziciją. Taip pat reikètu išsamiau ištirti, kaip greitumo lavinimo pratybos ir kalcineurino slopinimas veikia jègą esant labai dideliam raumenų susitraukimo greičiui. Tai aktualu, nes kalcineurino aktyvumo kontrolè ateityje gali būti taikoma ligoniams, sergantiems raumenu atrofijos ligomis (Sakuma, Yamaguchi, 2010), ir sportininkams, siekiantiems geresnių rezultatų lavinant raumenų susitraukimo greiti, galingumą ir jègą.

\section{IŠVADOS}

Po greitumo lavinimo pratybų ciklo padidèjo bėgimo isigreitejus tempiant guma (palengvintomis sąlygomis) ir paprasto bėgimo isigreitèjus greitis, tačiau sprinto bėgimo iš aukšto starto tempiant svorị ir paprasto bėgimo iš aukšto starto rezultatai nepakito.

Didžiausio greitumo pratybos nepakeitè šuolio í aukštị iš vietos amortizuojamai pritupiant ir šuolio i aukšti iš padèties pusiau pritūpus rezultatu.

Greitumo pratybu ciklas neigiamai paveike didesnès jẻgos reikalaujančiu pratimu (kojos tiesimo ir lenkimo $30^{\circ} / \mathrm{s}$ greičiu) rezultatus, nors didesniais kampiniais greičiais atliekamų judesiu galingumas išliko panašus.

Padėka. Dėkojame prof. Aleksui Stanislovaičiui, padẻjusiam atlikti tyrimą. 


\title{
LITERATŪRA
}

Andersen, L. L., Andersen, J. L., Magnusson, S. P. (2005). Changes in the human muscle force-velocity relationship in response to resistance training and subsequent detraining. Journal of Applied Physiology, 99 (1), 87-94.

Bodine, S. C., Stitt, T. N., Gonzalez, M. et al. (2001). Akt/ mTOR pathway is a crucial regulator of skeletal muscle hypertrophy and can prevent muscle atrophy in vivo. $\mathrm{Na}$ ture Cell Biology, 11, 1014-1019.

Brooke, M. H., Kaiser, K. K. (1970). Muscle fiber types: How many and what kind? Archives of Neurology, 23, $369-379$.

Chin, E. R., Olson, E. N., Richardson, J. J. et al. (1998). A calcineurin-dependent transcriptional pathway controls skeletal muscle fiber type. Genes \& Development, 12, 2499-2509.

Deschenes, M. R., Holdren, A. N., McCoy, R. W. (2008). Adaptations to short-term muscle unloading in young aged men. Medicine and Science in Sports and Exercise, 40 (5), 856-863.

Donati, A. (1995). The development of stride length and stride frequency in sprinting. IAAF. New Studies in Athletics, 1, 51-66.

Dunn, S. E., Burns, J. L., Michel, R. N. (1999). Calcineurin is required for skeletal muscle hypertrophy. Journal of Biological Chemistry, 31, 21908-21912.

Harre, D. (1994). Training der Ausdauer. Trainingswissenschaft (pp. 349-365). Berlin: Sportverlag.

Hoey, T., Sun, Y. L., Williamson, K., Xu, X. (1995). Isolation of two new members of the NFAT gene family and functional characterization of the NFAT proteins. Immunity, 2, 461-472.

Karoblis, P. (2003). Jaunojo sportininko pratybos. Vilnius: Lietuvos sporto informacijos centras.

Komi, P. V. (1992). Strength and power in sport. In The
Encyclopedia of Sports Medicine. Oxford: IOC Medical Commission, Blackwell Scietific. P. 404.

Mitchell, P. O., Mills, S. T., Pavlath, G. K. (2002). Calcineurin differentially regulates maintenance and growth of phenotypically distinct muscles. American Journal of Physiology, 5, 984-992.

Oh, I. M., Rybkin, I., Copeland, V. et al. (2005). Calcineurin is necessary for the maintenance but not embryonic development of slow muscle fibers. Molecular and Cellular Biology, 15, 6629-6638.

Sakuma, K., Akiho, M., Nakashima, H. et al. (2008). Cyclosporin A modulates cellular localization of MEF2C protein and blocks fiber hypertrophy in the overloaded soleus muscle of mice. Acta Neuropathologica, 6, 663-674.

Sakuma, K., Yamaguchi, A. (2010). The functional role of calcineurin in hypertrophy, regeneration, and disorders of skeletal muscle. Journal of Biomedicine and Biotechnology, 10, 1155.

Sreter, F. A., Lopez, J. R., Alamo, L., Mabuchi, K., Gergely, J. (1987). Changes in intracellular ionized $\mathrm{Ca}^{2+}$ concentration associated with muscle fiber type transformation. American Journal of Physiology, 253, C 296-300.

Stanislovaitis, A., Grūnovas, A., Butkus, V. (2006). Trumpuju nuotoliu bégimas. Kaunas: LKKA.

Widrick, J. D., Stelzer, E. J., Shoepe, T. C., Garner, D. P. (2002). Fuctional properties of human muscle after short resistance training. American Journal of PhysiologyRegulatory, Integrative and Comparative Physiology 283, R 408-416.

Williams, R. S., Salmons, E. A., Newsholme, R. E., Kaufman, J. M. (1986). Regulation of nuclear and mitochondrial gene expression by contractile activity in skeletal muscle. The Journal of Biological Chemistry, 261, 376-380.

Озолин, Н. Г. (2002). Настольная книга тренера: наука побеждать. Москва: Астрель.

\section{HOW DOES FACILITATED RUNNING TRAINING IMPACT MUSCLE FORCE-VELOCITY RELATIONSHIP?}

\author{
Juozas Baltušnikas, Evaldas Dinevičius, Tomas Venckūnas \\ Lithuanian Academy of Physical Education, Kaunas, Lithuania
}

\begin{abstract}
Contraction velocity and speed of relaxation are among the most important muscle characteristics. The speed and rate of movements, including stride frequency during running (which is the major form of locomotion during different sports and recreational activities), are of primary importance for the maximal power output or running speed. To attain fast running velocity, high rate of muscle contraction and relaxation are indispensable, though not sufficient: in addition to good motor skills, high level of other physical characteristics such as force generation capacity is required. That is why the development of strength is also emphasized during training in the preparation for sprint running competitions. Importantly, high level of strength seems to interfere with the ability to generate rapid movements due to decreased ability to quickly contract and relax skeletal muscle. To our knowledge, one of the hottest issues and one of the biggest
\end{abstract}


problems in sports practice as well as exercise physiology is the lack of understanding how to increase muscle strength and not to loose its capacity of speedy contraction and relaxation, thus rendering skeletal musculature ready to produce high power when athlete needs it during the competition.

The aim of the study was to investigate how facilitated sprint running training influences muscular capacities to generate power at different resistance and/or shortening velocity.

Seven healthy untrained adult males volunteered for the study (age $25.7 \pm 3.7 \mathrm{yrs}$; height $179.0 \pm 4.7 \mathrm{~cm}$; body mass $77.6 \pm 8.4 \mathrm{~kg}$ ). The study consisted of three parts. The initial and the final parts being identical and consisting of counter movement jump and static jump heights, isokinetic knee extension and flexion peak torques were measured at different speeds (30 to $210^{\circ} / \mathrm{s}$ ) as well as $20 \mathrm{~m}$ running from standing position with weight brake followed by $20 \mathrm{~m}$ running from standing without weight brake followed by $20 \mathrm{~m}$ flying run assisted by pulling with rubber band the $20 \mathrm{~m}$ fluing run was performed prior and afterwards the training program, which was initiated in a week after the initial testing and was consisted ten training sessions dedicated mainly to $20 \mathrm{~m}$ flying runs for up to ten reps under assisted conditions until the speed started to decline. In five days after the block of these ten workouts, subjects were re-tested in the lab for sprinting capacities under different conditions, as described above. All efforts were made by the researchers and the subjects to ensure maximal exertion during all the tests and training sessions.

Overspeed training decreased the time required to cover the $20 \mathrm{~m}$ distance in normal flying run and also facilitated sprint running $(\mathrm{p}<0.01)$, with supramaximal speed showing a clear tendency to increase more than normal flying speed. The results of $20 \mathrm{~m}$ dash from standing position or $20 \mathrm{~m}$ dash from standing position with weight brake (ten percent of body mass) did not change significantly ( $p>0.05$ ). Also, supramaximal speed workouts did not change either squat or counter movement jumping abilities. Surprisingly though it was, our untrained volunteers ended up the program with a significantly $(\mathrm{p}<0.01)$ reduced peak torque during slow $\left(30^{\circ} / \mathrm{s}\right.$, i. e. low contraction speed) isokinetic knee extension as well as knee flexion. However, at higher muscle contraction velocities (60 to $210^{\circ} / \mathrm{s}$ ) the peak power of neither knee flexors nor extensors changed.

Keywords: maximal running speed, facilitated sprint running, supramaximal velocity, overspeed training, adaptation.

Gauta 2010 m. gegužès 6 d.

Received on 6 May, 2010

Priimta 2010 m. gegužès $31 \mathrm{~d}$.

Accepted on 31 May, 2010

Juozas Baltušnikas

Lietuvos kūno kultūros akademija

(Lithuanian Academy of Physical Education)

Sporto g. 6, LT-44221 Kaunas

Lietuva (Lithuania)

Tel +37063089227

E-mail j.baltusnikas@nemesis.lt 